https://doi.org/10.26593/sentris.v2i1.4564.59-72

\title{
The Legitimacy of Bougainville Secession from Papua New Guinea
}

\author{
Muhammad Sandy Ilmi
}

Faculty of Social and Political Sciences, Universitas Katolik Parahyangan, Indonesia, sandy.ilmi2303@gmail.com

\begin{abstract}
What started as a movement to demand a distributive justice in mining revenue in Bougainville, Papua New Guinea, the conflict turned into the struggle for secession. From 1970's the demand for secession have been rife and despite early agreement for more autonomy and more mining revenue for the autonomous region, the demand never faded. Under Francis Ona's Bougainville Revolutionary Army, the movement take a new heights. Bougainville Revolutionary Army took coercive measure to push the government to acknowledge their demands by taking over the mine at Panguna. Papua New Guinean government response was also combative and further exacerbate the issue. Papua New Guinean Defense Force involvement adding the issue of human rights into the discourse. This paper will seek to analyze the normative question surrounding the legitimacy of the right to secession in Bougainville Island. The protracted conflict has halted any form of development in the once the most prosperous province of Papua New Guinea and should Bougainville Island become independent, several challenges will be waiting for Bougainvilleans.
\end{abstract}

Keywords: Bougainville secession; Papua New Guinea conflict; mining injustice; human rights violation

\section{ABSTRAK}

Berawal dari bentuk perlawanan untuk mencapai keadilan dalam pembagian keuntungan dari sektor pertambangan, kemudian berubah menjadi perjuangan untuk memisahkan diri dari Papua Nugini. Sejak 1970an, dukungan untuk pemisahan diri telah mendominasi diskursus politik di Bougainville dan walaupun perjanjian sempat tercapai, keinginan untuk pemisahan diri tidak pernah padam. Di bawah pimpinan Francis Ona, Bougainville Revolutionary Army menjadi organisasi yang menggunakan cara koersif untuk mendesak pemerintah memenuhi keinginan untuk pembagian yang adil dan pemisahan diri. Bougainville Revolution Army berhasil mengambil alih tambang di Panguna dan pemerintah Papua Nugini meresponnya dengan menurunkan Papua New Guinea Defense Force, yang melakukan berbagai pelanggaran hak asasi manusia, memperparah kondisi di Bougainville. Artikel ini akan membahas pandangan normatif mengenai legitimasi hak untuk memisahkan diri dalam kasus Kepulauan Bougainville. Konflik yang berkepanjangan telah membuat pembangunan di Bougainville menjadi terhambat. Hal ini telah menyebabkan Bougainville yang dulunya merupakan provinsi termaju di Papua Nugini dan menjadi tulang punggung negara harus menghadapi banyak tantangan jika kemerdekaan berhasil tercapai.

Kata Kunci: pemisahan diri Bougainville; konflik Papua Nugini; mining injustice; pelanggaran hak asasi manusia 


\section{Introduction}

Occupying the eastern area of New Guinea Island, Papua New Guinea is an independent state which stretches until the offshore islands of Melanesia. With Port Moresby as its capital, the state had only gained their independence in 1975 after 60 years of Britain's occupation. Papua New Guinea is also one of the world's most diverse state. It has 851 languages with as many as eleven languages said to not have a known speaker. There are also mostly live in rural area with many of them still practice clan-based leadership. The fact that local elected government just established as early as 1950, makes Papua New Guinea still hold on to their clan-based society. Their economy heavily dependent with their natural resource and agriculture, with as many as $85 \%$ of their workforce working in agriculture. They also have a strong relation with Australia, as Australia become their biggest import as well as export partner. ${ }^{1}$

Bougainville Island is one of Papua New Guinea's autonomy region located at the border between Papua New Guinea and Solomon Islands. The Bougainville Island or also called as North Solomon Province covers the total landmass of $9,438 \mathrm{~km}^{2}$ ( $2 \%$ of Papua New Guinea overall landmass) and consist of 300,000 residents (4\% of total Papua New Guinea's population). The province has a strong proximity to Solomon Islands geographically, culturally and linguistically, and at large, its population have a darker skin color compared to mainland Papua New Guinean. Bougainvillean is consist of heterogeneous clan-based society of around 50 to 150 people and have a strong customary arrangement. Unlike most part of Papua New Guinea, most Bougainvillean adopt matrilineal system of hereditary and used performance-based leadership. ${ }^{2}$ The area was part of Germany colonial administration alongside the Solomon Islands from 1884 to 1915, but did not ceded to the United Kingdom. They were taken under Australian jurisdiction instead, until 1975. ${ }^{3}$

Australian occupation of Bougainville Island provoked the emergence of first support for secession. The area has long been known to have one of the world's abundance copper reserves and also known to be the source of cocoa cultivation. Bougainvillean also relatively more educated and have a better access to health service compared to mainland Papua New Guinea. ${ }^{4}$ In 1964, Bougainville Copper Limited, an Australian based company, started mining operation in Panguna, without proper involvement and compensation for the locals. This is led to Bougainvillean first attempt to secede in 1975 just before Papua New Guinea declared their independence. However, they received zero international recognition and finally settled for a constitutional basis for provincial government of Papua New Guinea in $1977 .^{5}$

However, the arrangement is far from satisfying according to Bougainvillean landowner. Bougainvillean landowner only gain $1 \%$ of the total revenue of the Panguna mine. They demand a new term that will reward them more from the mining revenue as well as ecological responsibility from Bougainville Copper Limited. Multiple failure in negotiation of the new term then led to the establishment of Bougainville Revolutionary Army under the leadership of Francis Ona. Since then,

${ }^{1}$ CIA, "World Factbook: Papua New Guinea", https://www.cia.gov/library/publications/the-world-factbook/geos/pp.html (accessed on December 21, 2020)

${ }^{2}$ Regan, Anthony. "The Bougainville Referendum Arrangements: Origins, Shaping, and Implementation”, Australian

National University Discussion Paper 2018/4 (2018), 2-3.

${ }^{3}$ John Connell, “Bougainville: A New Pacific Nation?”, Small States \& Territories Vol. 3 No. 2 (2020), 377.

${ }^{4}$ M. Rafiqul Islam, "Secession Crisis in Papua New Guinea: The Proclaimed Republic of Bougainville in International Law", University of Hawaii Review Vol. 13 No. 2 (1991), 453.

${ }^{5}$ John Connell, “Bougainville: A New Pacific Nation?”, 379. 
Bougainville Island have been plagued by internal conflict between Bougainville Revolutionary Army and Papua New Guinean government as well as pro-secession and anti-secession Bougainvillean. ${ }^{6}$

This conflict took a toll on Bougainville, not only that many government facilities are destroyed, they are also having limited access to food commodities through economic embargo placed by Port Moresby. Nonetheless, it is also important to note that Papua New Guinea also having the downside of their own. Once wealthiest province of Papua New Guinea and heavily supporting Papua New Guinea's economy, the province fell into further chaos and disarray. By 1972, revenue from Bougainville Island contributed to $17 \%$ of Papua New Guinea's national revenue, $45 \%$ of national export, and USD1 million/day for the national treasury. ${ }^{7}$ These contributions vanished after the conflict erupt and Bougainville Revolutionary Army took over the mining facility in Panguna. Since then, Papua New Guinea have been sustained by foreign aid, most notably from Australia.

This paper seeks to analyse the legitimacy of Bougainville Island secession from Papua New Guinea by using remedial right only theory (RRO). The writer argues that the secession movement is legitimized. The evidence of mining injustice and human right violation by Papua New Guinean government, support the notion of the legitimacy of Bougainvillean secession effort. Despite the newly held referendum, this paper will only focus on the first and second unilateral declaration of independence in Bougainville in analyzing the legitimacy of the secessionist movement. This paper also takes a look at the future prospect of independent Bougainville Island and implication of human rights violation by the secessionist movement to the normative question on legitimacy of secession in Bougainville.

\section{Literature Review}

Scholars have long been debating the legitimacy of secessionist movement in Bougainville Island. The case is considerably complex involving economic, social, cultural, and human rights implication from both side of the parties. Each scholar offering different criteria in their views on the legitimacy of secession in Bougainville. Scholar such as M. Rafiqul Islam sees this case through international law lenses. Almost similar to Islam, Roderic Alley compares legal argument between Bougainville Revolutionary Army and Papua New Guinea government, while Anthony Matthews traced historical events that influence secessionist movement in Bougainville Island. On the other hand, John Connell made future possible prospect of independent Bougainville. This section will examine Islam, Alley, Matthews, and Connell views on the legitimacy of the secession in Bougainville.

Islam in his journal article titled "Secession Crisis in Papua New Guinea: The Proclaimed Republic of Bougainville in International Law" argues that both unilateral declarations of independence are 'extra-legal'. There is no law which stated that such declaration in prohibited under international law, this is when the international recognition become important. However, Islam highlights the issue of human rights violations as a possible deal breaker. Human rights violations

\footnotetext{
${ }^{6}$ Anthony Matthew, "Bougainville and Papua New Guinea: Complexities of Secession in a Multi-Ethnic Developing State", Political Studies Vol. 48 No. 4 (2000), 735.

${ }^{7}$ M. Rafiqul Islam, "Secession Crisis in Papua New Guinea: The Proclaimed Republic of Bougainville in International Law", 465 .
} 
conducted by both the Papua New Guinea government and the secessionist movement would make international recognition for the new state difficult to achieve. International law allowed state the right to suppress rebellion to maintain order but subsequently, international law also allow the acquisition of independence through revolutionary means. This shows how the issue of secession is still underdeveloped within international law. ${ }^{8}$

Roderic Alley also offers international law approaches to the issue. However, he focuses on comparing both sides legal arguments to determine which side has the best chance for international recognition and support. Bougainville Revolutionary Army have four legal arguments. They argue that first, identity linkage to neighboring Solomon Island makes them separate entirely from mainland Papua New Guinean. Second, denial of the option of plebiscite before Papua New Guinea declaration of independence is a violation of UN General Assembly resolution 1541(XV). Third, Bougainville is more than viable to be independent with the abundance of copper resource. And last, Bougainville was not part of Papua New Guinea hence why self-determination cannot be considered as a threat to territorial integrity as stated on 1970 UN Declaration on Principles of International Law. ${ }^{9}$

On the other hand, the Papua New Guinean government argue that Bougainvillean is not a cohesive group as they do not share a single language or culture. They also argue that Bougainvillean elected representatives have given their blessing for Bougainville to join Papua New Guinea and that Papua New Guinea have an obligation to maintain territorial integrity to retain colonial boundaries as attempt to change the colonial boundary always resulted in further conflict. Judged by both legal arguments, Alley argues that the Bougainville Revolutionary Army have a strong case for selfdetermination. However, similar to Islam, Alley also highlights Bougainville Revolutionary Army's human rights violations record. Coupled with the fact that they have not negotiating in principle of good faith and that they are not elected by the people. That makes their legal arguments could easily dismissed. $^{10}$

Anthony Matthew on his journal article titled "Bougainville and Papua New Guinea: Complexities of Secession in a Multi-Ethnic Developing State", offers five criteria to determine the legitimacy of secessionist movement in Bougainville. These five criteria include: political consent, national identity, cultural preservation, distributive justice, and territorial justice. Each of these criteria is important however, will not be sufficient on its own. Matthew argues that in the case of Bougainville Island, the notion of distributive justice is a key element. Although there are also traits of political consent for independence, national identity which differs from the rest of Papua New Guinea, threat to cultural preservation in the form of ancestor's land being used for mining, and the fact that the inclusion of Bougainville to Papua New Guinea is part of western colonialism, all these traits could easily brush aside. Hence why Matthew concludes that secession only provide a short-term solution to the real problem of mining injustice in the area and rejects the idea. Matthew suggests a renegotiation for a new mining deal and provision of more autonomy for the Bougainvillean. ${ }^{11}$

\footnotetext{
${ }^{8}$ M. Rafiqul Islam, "Secession Crisis in Papua New Guinea: The Proclaimed Republic of Bougainville in International Law", 453-476.

${ }^{9}$ Roderic Alley, "Ethnosecession in Papua New Guinea: The Bougainville Case", in Rajat Ganguly and Ian Macduff, Eds., Ethnic Conflict and Secessionism in South and Southeast Asia: Causes, Dynamics, and Solutions (New Delhi: SAGE India, 2003), 225-253.

${ }^{10}$ Roderic Alley, "Ethnosecession in Papua New Guinea: The Bougainville Case", 225-253.

${ }^{11}$ Anthony Matthew, "Bougainville and Papua New Guinea: Complexities of Secession in a Multi-Ethnic Developing State", 724-744.
} 
John Connell offers yet another different view on the case. Connell takes a look at the possible future Bougainville Island if the island decided to be independent. Connell argues that there are three key elements on why the secession should be granted for Bougainvillean: cultural distinctiveness from the rest of Papua New Guinea, rights to determine political destiny through referendum, and viability of economy. Connell compares Bougainville to Nauru, another small island state, that is able to sustain their economy through mining. Bougainville Island also could take an advantage over their strategic position which lately drawn up interest from China and New Zealand. Nevertheless, Connell acknowledges that a unilateral declaration of independence will not be enough. Bougainville Island will still need Papua New Guinean government goodwill on this issue as they will still heavily dependent to Papua New Guinea in the early years of their new state. ${ }^{12}$ In this paper, however, the writer will not side with any of the said scholars as this paper will be using remedial rights only theory to analyse the case of Bougainville.

\section{Theoretical Framework}

There are many debates on what would consider as secession. Would what happen to Yugoslavia considered as secession? What about what happened to the Soviet Union? The term secession itself refers to a separation of a part of population and territory from a state to create a new state which has a similar sovereignty. ${ }^{13}$ From the said definition it could be concluded that secession will not be followed by the vanishing of the parent state. Hence why what happened to Yugoslavia is not secession, but dissolution. On the case of Soviet Union, what happened were a series of secessions which could be called dismemberment whereas Russian Federation assume as the succession state of Soviet Union. Secession of the periphery is the most common type of secession. Many seceding territory is located at the periphery of the state. ${ }^{14}$ It is rare for a territory located at the center of the state to seek secession and risk being an enclave if they are able to gain theirindependence.

The theories of secession can be classified into two big theories: primary right theory and remedial right only theory. Both theories provide normative answer to the legitimacy of secession that is not addressed on international legal norms. Remedial right only theory suggest that secession is allowed if selective group of people living under an unjust rule and that secession promise to relief this group from the grave injustice. Under remedial right only theory, secession is also seen as a last resort if other means have been unsuccessful to resolve the issue. What is then considered as unjust rule? According to Schmücker, it is considered unjust if the state tolerates or commit grave violation of human rights. Furthermore, it is also allowed to secede if the territory was once annexed or illegally occupied and if the state violate an already established intrastate autonomous arrangement. ${ }^{15}$

Besides of the three causes stated by Schmücker, Busquets also add the possibility of distributive injustice as a cause which legalize secession. However, the distributive injustice should be listed as disadvantages and differences that cannot be morally justified. It could be in the form of

\footnotetext{
${ }^{12}$ John Connell, “Bougainville: A New Pacific Nation?”, 375-393.

${ }^{13}$ Pau Bossacoma Busquets, Morality and Legality of Secession: A Theory of National Self-Determination (Switzerland: Palgrave Macmillan, 2020), 5-7.

${ }^{14}$ Pau Bossacoma Busquets, Morality and Legality of Secession: A Theory of National Self-Determination, 7.

${ }^{15}$ Reinhold Schmücker, "Remedial Theories of Secession", in Aleksandar Pavkovic and Peter Radan, Eds., The Ashgate Research Companion to Secession (London: Routledge, 2011), 399-401.
} 
economic exploitation or/and economic marginalization. ${ }^{16}$ Both Schmücker and Busquets did not offer these causes as a prerequisite for the legitimation of the secession, rather as Schmücker put it, secession is legitimized if it frees people from unjust rule. ${ }^{17}$ In other word, any of the unjust case presented would normatively made the secession legitimize.

There are also three special rights for a territory to secede according to the remedial right only theory:

- The state grants a right to secede,

- State's constitution has a clause for the right to secede,

- State was created from separate independent state which has implicit or explicit assumption that secession is allowed. ${ }^{18}$

The theory also offers some restriction for secession. These restrictions include time limit to restitutive secession and the new state should not be unjust to its citizen.

\section{Analysis}

\section{a. Bougainville Secession: History and Development}

Bougainville Island historically been under Germany colonization from 1884 to 1915 and under Australia from 1915 to 1975. In the 1960s, Australia first began their mining industry in Panguna. Through Bougainville Copper Limited, mining become the main source of income in Bougainville, making the island become the wealthy but also subsequently increase the disparities in the island. The mining industry disregard social and environmental impact felt by Bougainvillean. The Australian company dumped their waste in Kawerong banks and Jaba Rivers, changing it flows and poison the river. Bougainvillean also have limited land rents and compensation from the copper mines. The Bougainville Copper Limited failed to understand the dynamic of landownership in Bougainville which are matrilineal. By listing the men as landowner, many of the rightful owner felt they do not receive adequate compensation for their relocation. ${ }^{19}$

The marginalization of mining compensation led to the first real sense of common identity. The island itself have been known as heterogeneous as there was nineteen language groups and 35 dialects in the islands. ${ }^{20}$ It was mining injustice that finally sparks the emergence of PanBougainvillean identity. The Pan-Bougainvillean identity highlights their differences to mainland Papua New Guinean by comparing the darker skin color of Bougainvillean. Pan-Bougainvillean movement also highlights how the two main churches in Bougainville have a close links to 'parent' church in Solomon Islands. The movement also highlight the economic neglect during colonization and an ongoing mining industry which disregards the locals. ${ }^{21}$

\footnotetext{
${ }^{16}$ Pau Bossacoma Busquets, Morality and Legality of Secession: A Theory of National Self-Determination, 131-132.

${ }^{17}$ Reinhold Schmücker, "Remedial Theories of Secession", 401.

${ }^{18}$ Allen Buchanan, "Theories of Secession", Philosophy and Public Affairs Vol. 26 No. 1 (1997), 36.

${ }^{19}$ Government of Australia, "History of Bougainville Conflict",

https://www.aph.gov.au/parliamentary_business/committees/house_of_representatives_committees?url=jfadt/bougainville/bv

chap2.pdf, 20. (Accessed on December 21, 2020)

${ }^{20}$ Ibid, 15.

${ }^{21}$ Anthony Regan, “The Bougainville Referendum Arrangements: Origins, Shaping, and Implementation”, 1-4.
} 
This Pan-Bougainvillean movement then results in the push for referendum during Papua New Guinea early struggle for independence. In September 1968, 25 Bougainvillean in Port Moresby requested the referendum to be held in 1970 with options to be independent, unite with Solomon Islands, or remain with Papua New Guinea. The request was denied and the following year, Napidakoe Navitu established. Napidakoe then became Bougainvillean main platform to voice their support for the referendum. In 1971, Paul Lapun, the chairman of Napidakoe and a representative of Bougainvillean on the House of Assembly once again introduce a bill for Bougainville referendum that is once again denied. The tension is rising in 1972 as two Bougainvillean that involved in a car accident killing a child, found killed. Both parties finally able to reach an agreement on special autonomy for Bougainville once Papua New Guinea become independent in 1973. However, the talks over the mining share revenue still become an issue that in 1974, Chief Minister of Papua New Guinea, Somare remove the previously agreed constitutional arrangement. Feeling betrayed, Bougainville declared an independence on September 1, 1975 just fifteen days before Papua New Guinea declare their independence. ${ }^{22}$

The unilateral declaration of independence downplayed by Somare and Papua New Guinea kept going with their declaration of independence. With no resolution or any effort of reconciliation, on January 1976 small group of rebellion destroyed government property and airstrip. The Papua New Guinean government responded by deploying riot police squad on June. With continuous pressure from the riot police and the failure to secure international recognition, both parties finally agreed to 1976 constitutional arrangement which granted the province of North Solomon 95\% of its mining revenue and 5\% for the landowner. ${ }^{23}$ The agreement marks the end of Bougainville island first attempt at secession. However, the sentiment for secession remains high among Bougainvillean.

The secessionist movement once again emerge under the leadership of Francis Ona. Ona is a second-generation landowner and receive scarce rent and compensation. Ona worked at the mine as surveyor and driver for Bougainville Copper Limited. However, in Arawa on 1988, a New Zealand company is invited to review the environmental impact of Bougainville Copper Limited. The verdict was that the company was not fully to blame for the environmental degradation. This verdict led to Ona resigning from Bougainville Copper Limited and established Bougainville Revolutionary Army. ${ }^{24}$ The Bougainvillean Revolutionary Army demanded that Bougainville Copper Limited to pay K10 billion, a fifty percent share in profit, and the localization of the company. Despite the emerging support of secession, it was not part of early Bougainville Revolutionary Army demands. ${ }^{25}$

In order to get more support for their movement, Ona finally incorporated the demand for secession to his Bougainville Revolutionary Army. Ona started many operation with an aim to disrupt the mining operation in Panguna. The riot police is once again deployed to Bougainville. The dispatch of riot police worsened the situation as they were contributed in the burning of civilian houses and harassment towards civilian. In 1989, Papua New Guinea Defense Force also deployed to help the riot police. The deployment marks the start of generalized violence against Bougainvillean. The defense force was also responsible for St. Valentine's Day Massacre on March. ${ }^{26}$ The widespread violence

\footnotetext{
${ }^{22}$ Anthony Regan, “The Bougainville Referendum Arrangements: Origins, Shaping, and Implementation”, 4.

${ }^{23}$ Ibid.

${ }^{24}$ John Connell, "Bougainville: A New Pacific Nation?”, 380.

${ }^{25}$ Government of Australia, "History of Bougainville Conflict", 21-22.

${ }^{26}$ Ibid, $22-23$.
} 
then led to the closing of the mine in May 1989. Ona then declared the second unilateral declaration of independence by declaring the Republic of Me'ekamui in 1990. This time the Papua New Guinean government responded by blocking Bougainville from outside world for four years and withdrew the Papua New Guinean force. The blockade was supported by Bougainville Copper Limited which supply the Papua New Guinean government with helicopter. ${ }^{27}$

With the absence of Papua New Guinean troops, Bougainville Revolutionary Army take control of Bougainville and established Bougainville Interim Government with Ona as their president. The Bougainville Interim Government able to established a council of chief and some sort of government in Bougainville. However, with the Ona could not control all of Bougainville Revolutionary Army, some started their own new mission by targeting rich non-Bougainvillean which they suspect as pro-Papua New Guinea. This is led to the emergence of resistance forces which is supported by the Papua New Guinean government. The 1990's became the Bougainvillean civil war. Ona received support from the North and mining area, while in the South many starts to question Ona as violence involving Ona's Bougainville Revolutionary Army become more widespread. ${ }^{28}$

Despite peace talks taking place during the 1990's, the conflict is still rife. Endeavor Accords and Honiara Declaration provide early suggestion of possible conflict resolution in the area. However, in 1995 after a peace talk in Cairns, Australia, the delegation of Bougainville Revolutionary Army got ambushed by Papua New Guinea Defense Forces, further set back the peace processes. ${ }^{29}$ The ceasefire was lifted in 1996 and Kangu Beach Massacre saw twelve defense forces killed and five others taken hostage. ${ }^{30}$ This signify a high level of distrust between both parties. After a series of long negotiation between June 1999 to August 2001, finally both parties can agree on Bougainville Peace Agreement which includes future referendum arrangement. The referendum finally taking place in December 2019. The referendum had two options: more autonomy from Papua New Guinea or to be independent. The votes overwhelmingly favor independence with $98 \%$ voted for independence. The result, however, is not binding and to be decided by parliament of Papua New Guinea as per the Bougainville Peace Agreement. There are pressures with the referendum that the Papua New Guinea finally have to let Bougainville go. It is remained to be seen what will the government do with the results. $^{31}$

\section{b. Legitimacy of Secession in Bougainville: Human Rights Violation and Mining Injustice}

The appeal for secession in Bougainville has resulted in a protracted conflict in the area. Will the secession claim is considered normatively legitimized? According to remedial right only theory, a secession claim could be considered legitimized if there is a grave human rights violation, territorial injustice, violation of autonomous arrangement, and in some cases economic injustice. In this section, the writer will analyze if there is any of these traits apparent in Bougainville secessionist claim. First, it is mentioned that secession is legitimized if the state tolerates, support, or commit grave violation of human rights. Secession is even more likely in the case of selective human rights violation. ${ }^{32}$ In the case of Bougainville, as many as 10,000 to 15,000 civilians were killed during the protracted conflict

\footnotetext{
${ }^{27}$ John Connell, "Bougainville: A New Pacific Nation?”, 381.

${ }^{28}$ Government of Australia, "History of Bougainville Conflict", 25.

${ }^{29}$ Anthony Regan, "The Bougainville Referendum Arrangements: Origins, Shaping, and Implementation", 7.

${ }^{30}$ Government of Australia, "History of Bougainville Conflict", 29.

${ }^{31}$ BBC, "Bougainville Referendum: PNG Region Votes Overwhelmingly for Independence”, December 11, 2019, https://www.bbc.com/news/world-asia-50739203 (accessed on December 21, 2020)

${ }^{32}$ Pau Bossacoma Busquets, Morality and Legality of Secession: A Theory of National Self-Determination, 129.
} 
between Bougainville Revolutionary Army and Papua New Guinea Defense Force. Papua New Guinea Defense Force is said to be involved in burning of civilian houses and conducting 'Vietnamstyle' search and clear operations. ${ }^{33}$ The Papua New Guinea Defense Forces also responsible for St. Valentine's Day Massacre on March 1989. On the massacre, at least five bodies were dumped into the ocean by the Defense Force. ${ }^{34}$ The Defense Force also responsible for the chemical spray of food gardens and jungles in Kongara which then poisoned people's source of food. ${ }^{35}$ Not only that this entails serious violation of human rights by Papua New Guinean government it is also prove that the government cannot solemnly perform their duty to protect their own citizen.

Second, on the issue of territorial injustice is not as clear forward as the issue of human rights violation. Bougainville island was part of Germany's Papua New Guinea until 1915 before the United Kingdom secede the control of the island under the trusteeship of Australia. Despite their early reluctance to join Papua New Guinea earlier, their main goal was always to gain more autonomy from Papua New Guinea instead of to secede. ${ }^{36}$ They ended up agreeing on the constitutional arrangement for North Solomon Province in 1976. With the historical background connecting mainland Papua New Guinea and Bougainville island, as well as no initial effort from Papua New Guinean government to annex Bougainville during the negotiation period pre-independence, Bougainville island has no right to secede under the principle of territorial injustice.

The third cause which could legitimize a secession is the violation of autonomous arrangement. During a heated tension for more autonomy, the Papua New Guinean government and Bougainville representative actually manage to reach an agreement on Interim Bougainville Provincial Government in 1973. This agreement later revoked by Chief Minister Somare in 1974 which then consequently led to the first unilateral declaration of independence of Republic of North Solomon in 1975. ${ }^{37}$ Would this act by Chief Minister Somare considered a violation of autonomous arrangement? The arrangement of Interim Bougainville Provincial Government will be part of the Papua New Guinea Independence Constitution. The constitution has not yet been on effect in 1974 as Papua New Guinea independence declared and recognized on September 16, 1975. With that, the argument over the legitimacy because of a violation of autonomous arrangement is not valid.

The last cause is the economic injustice as a legitimate cause for secession. There are two ways in which economic injustice could take form: economic exploitation and economic marginalization. Economic exploitation happens when a state exploit economic of a certain territory without regards for the redistribution of wealth. On the other hand, economic marginalization is when a state favoring a territory for the development of facilities without morally justifiable reasons. ${ }^{38}$ Papua New Guinean government had been heavily supported by the mining revenue from Bougainville. The mining revenue accounted for $17 \%$ of national revenue, $45 \%$ of national export, and contribute to USD1 million per day for the national treasury. ${ }^{39}$ Yet the inequality could not be starker, even though

\footnotetext{
${ }^{33}$ M. Rafiqul Islam, "Secession Crisis in Papua New Guinea: The Proclaimed Republic of Bougainville in International Law", 467.

${ }^{34}$ Government of Australia, "History of Bougainville Conflict", 22-23.

${ }^{35}$ M. Rafiqul Islam, "Secession Crisis in Papua New Guinea: The Proclaimed Republic of Bougainville in International Law", 467.

${ }^{36}$ Anthony Regan, “The Bougainville Referendum Arrangements: Origins, Shaping, and Implementation”, 4.

${ }^{37}$ Ibid.

${ }^{38}$ Pau Bossacoma Busquets, Morality and Legality of Secession: A Theory of National Self-Determination, 131-132.

${ }^{39}$ M. Rafiqul Islam, "Secession Crisis in Papua New Guinea: The Proclaimed Republic of Bougainville in International Law", 465.
} 
Paguna mine employed a third of its worker locally, many from the affected land remain unemployed because they are unskilled. There are also uneven distribution of revenue and compensation. Not to mention an issue concerning the relocation. With many of these clan-based society depends on land to produce corps, the relocation and mining activity created less land available for locals. ${ }^{40}$ Not only that it created inequality between expatriates and local Bougainvillean, it also created inequality among Bougainvillean especially second-generation landowners. With the number shown how heavily Papua New Guinea dependent to mining industry in Bougainville and the unresolved issue of inequality and uneven shares of mining revenue, economic injustice became the strong case for secession in Bougainville. With little hope of a fruitful peaceful means to resolve the issue and how many peace talks ended in failure, secession can be seen a legitimize option for Bougainvillean.

Despite the absence of territorial injustice, the strong case of economic injustice and evidences of human rights violation provide a strong case for Bougainville to secede from Papua New Guinea. However, Papua New Guinea will oppose the secessionist claim for two main reasons. First, before the closing of the mine at Panguna, Bougainville mining have been a major source of income for Papua New Guinea. Since the closing, Papua New Guinea have been heavily dependent to international aid. Second, Papua New Guinea also have other possible secessionist movement emerging domestically in New Britain and New Ireland. Papua New Guinean government concern that if Bougainville secede from Papua New Guinea, it will prompt New Britain and New Ireland to also push for the similar secession. ${ }^{41}$

The first reason cause the real concern for the secession in Bougainville. Will the secession make Papua New Guinea stripped off of their main economy? The answer is no. Papua New Guinea have enough resources to still have a viable economy even after the departure of Bougainville. The former prime minister of Papua New Guinea, Michael Somare mentioned that Papua New Guinea will still have mines in Porgera, Misima, and Ok Tedi. ${ }^{42}$ It will be just the question of how the government should utilize it for the development in Papua New Guinea. All and all, with human rights violation, economic injustice, and the fact that Papua New Guinea would still have a viable economy, the secession of Bougainville normatively is legitimized.

\section{c. The Issue of Civilian Safety from Bougainville Revolutionary Army}

One of the restrictions when a new state seceding is no establishment of unjust state. Unjust state is a state that is not guaranteeing the safety of their citizen under the rule of law. If in the previous section, Papua New Guinean government have been found guilty to human rights violation, it is also important to note that Bougainville Revolutionary Army also contribute to some human right violation of their own. In the years after Papua New Guinea decided to withdraw their defense force from the island, Bougainville Revolutionary Army assume complete control over the island. With the absence of 'enemy' some of the army decided to target non-Bougainvillean civilian. They suspect that these non-Bougainvillean are pro-government. These new targets experience torture, harrassment, and even killing under Bougainville Revolutionary Army. ${ }^{43}$

\footnotetext{
${ }^{40}$ Anthony Regan, "Causes and Course of the Bougainville Conflict", Journal of Pacific History Vol. 33 No. 3 (1997), 275276.

${ }^{41}$ John Connell, "Bougainville: A New Pacific Nation?”, 386-393.

${ }^{42}$ Hugh Laracy, "Bougainville Secessionism”, Journal de las Sociéte des Océanistes No. 92 (1991), 58.

${ }^{43}$ Government of Australia, "History of Bougainville Conflict", 24.
} 
Question then being asked will the fact that Bougainville Revolutionary Army involvement in human rights violation negates the whole legitimacy of Bougainville secession? It is difficult to answer definitively. However, Smücker argue that a secessionist movement is legitimize even if it is violating the rights of the third party. ${ }^{44}$ In his statement, Smücker did not offer further explanation on what rights considered allowed to be violated. Busquets do recognize that in the process to gain the independence many secessionist movement might have to resort to military way. That being said, the violation of human rights might be justified for the right reason, in this case, to achieve secession. Furthermore, it would be useful to take a step back and analyse the issue in a broader perspective of just and unjust war. What would then considered as just? According to Clausewitz, in war both parties force each other into a decision which then create a reciprocal action that leads to continuum escalation. If one party decided not to act on other party's action, it would give their adversary an advantage. ${ }^{45}$ Clausewitz's perspective amplified the notion of 'all is fair in war'.

In the case of Bougainville Revolutionary Army violation of human right, the claim that the targetting are based on 'levelling' of Bougainville. Meaning that they try to create a more 'level' Bougainville in terms of social status and wealth. Hence why many of those targetted also rich, well educated and was senior government officer. Taken back to the historical context of the secessionist movement in Bougainville, it is important to note that Papua New Guinean Defense Force is responsible for the similar act of violence, as was the case on St. Valentine's Day Massacre. That qualified Bougainville Revolutionary Army's act as reciprocal action and rightly justified according to Clausewitz's perspective.

However, this levelling policy simply is not justified, nor it will help in the secession effort of Bougainville proposed by Smücker and Busquets. Will this pattern of act continued if Bougainville become independent? This is a huge question needed to be answered. If so, it is important to note that the creation of new unjust state is one of the determinants which might disqualified the right to secede. It is difficult to predict if Bougainville would be an unjust state if it is to be independent. Nevertheless, the independent state of Bougainville needs to make sure that those committed the violation need to be held accountable since it got nothing to do with the secessionist effort. In fact it is contributed to the establishment of resistance group which opposing Bougainville Revolutionary Army ideals in the South. All in all, the human rights violation by Bougainville Revolutionary Army might not negate the whole legitimacy claim for Bougainville to secede, but the offender would need to be held accountable even if Bougainville become independent.

\section{d. Future Prospects of Independent Bougainville Island}

Bougainville, if it become independent, would be similar to many other small island state in South Pacific. With approximately 300,000 people, Bougainville will need to be self-reliance. A study shows that Bougainville need to be able to exploit $56 \%$ of their resources to be self-reliance, however, currently it is estimated that with the closing of mining operation, Bougainville only able to utilize $6 \%$ of their total resources. Cornell has compared Bougainville economy to those of Nauru. Bougainville with its copper reserve can sustain their living just like Nauru with their phosphate. However, mining has long been a source for conflict in Bougainville and many still have dissenting view on the reopening of mine in Panguna. Even if the mine would be open again, significant cost of USD 4-6

\footnotetext{
${ }^{44}$ Reinhold Schmücker, "Remedial Theories of Secession”, 406.

${ }^{45}$ Michael Walzer, Just and Unjust War: A Moral Argument with Historical Illustration, (New York: Basic Books, 1977), 23
} 
million needed to invest in the infrastructure to support the mine. The development of supporting infrastructure also means that the mine can be active only as early as 2025. Other industries which could support self-reliance Bougainville is fisheries. According to Lowy Institute, fisheries in Bougainville accounted for $30 \%$ of fish catches in Papua New Guinea. This could be worth from 30 to 100 million Kina annually. ${ }^{46}$

Bougainville also will be blessed as they are standing geographically on the ongoing struggle of influence of China, Australia, and New Zealand. Bougainville also has made it clear that they want to benefit from this struggle for influence. Sam Kaouna said that "Bougainville is ... open for both Australia and China. We are ready ... and we need their money". China with their active policy have introduced China-Oceania-South Pacific Blue Economic Passage. China has long shown their interest in fisheries and mineral and will provide alliances with economic stimulus as how it has been happening in Solomon Islands and Kiribati. In exchange, China would want them to cut off any ties with Taiwan. ${ }^{47}$ Canberra also has made their presence felt in Bougainville, providing $12 \%$ of the bilateral aid program to Bougainville. ${ }^{48}$ On the other hand, Jacinda Ardern also has been vocal with her interest in the Pacific. Auckland launched their 'Pacific Reset' initiative in 2018 which provide millions of dollar for development and climate change mitigation for Pacific Islanders. ${ }^{49} \mathrm{New}$ Zealand also have shown their support for Bougainville to be independent by releasing a congratulatory press statement after the completion of the 2019 referendum. ${ }^{50}$

Bougainville also need to focus on how would they approach the problem of heterogeneity. As mentioned before, Bougainville will not be homogeneous with as many as eleven language groups with 35 dialects occupy Bougainville island. The emergence of Pan-Bougainvillean identity just occurred after the second World War. If Bougainville secede from Papua New Guinea, there are two possible problem. According to Buchanan, first, they can create a new minority within the new state. Second, not all of Bougainvillean is living within the seceding territory which could mean more discrimination to Bougainvillean living in mainland Papua New Guinea ${ }^{51}$ Multi-ethnic Bougainville and the split in support after the emergence of resistance force could pose a new internal conflict in Bougainville. Bougainville also need to make sure there is agreement established with Papua New Guinean government to protect any Bougainvillean living outside the province to be safe from persecution or discrimination.

\section{Conclusion}

The protracted conflict plagued Bougainville Island from 1970-1990's. Started as a demand for distributive justice of mining revenue in Panguna, the conflict turned into secessionist movement. Bougainvillean have long feel they do not relate to their 'redskin' counterpart in the mainland Papua New Guinea. The mining activities in 1960's by Bougainville Copper Limited conducted without

\footnotetext{
${ }^{46}$ Ben Bohane, "The Bougainville Referendum and Beyond", Lowy Institute, October 8, 2018, https://www.lowyinstitute.org/publications/bougainville-referendum-and-beyond (accessed on December 21, 2020)

${ }^{47}$ John Connell, “Bougainville: A New Pacific Nation?”, 388-389.

${ }^{48}$ Ben Bohane, "The Bougainville Referendum and Beyond".

${ }^{49}$ John Connell, "Bougainville: A New Pacific Nation?”, 388.

${ }^{50}$ Government of New Zealand, "NZ Congratulates PNG and Autonomous Bougainville Government on Referendum", December 12, 2019, https://www.beehive.govt.nz/release/nz-congratulates-png-and-autonomous-bougainville-governmentreferendum (accessed on December 21, 2020)

${ }^{51}$ Allen Buchanan, "Theories of Secession", 45.
} 
consultation and adequate retribution to Bougainvillean. This mining injustice and several human right violations by Papua New Guinea Defense Force during the secessionist conflict made the secessionist claim legitimize. However, there are still some debate on the fact that Bougainville Revolutionary Army also responsible for hostilities against non-Bougainvillean. Some argue that the hostilities by Ona's Bougainville Revolutionary Army signify the danger of the emergence of rouge state if Bougainville allowed to secede from Papua New Guinea. Furthermore, Papua New Guinean government still persist that the demand is only the demand of some and not the real representation of the voice of Bougainvillean. Perhaps, the government anxious that other territories such as New Britain and New Ireland will follow to secede next.

On the other hand, Bougainvillean is ready for the new start. They have explored the possibility to reopen their mine and the possibility of cooperation with China, Australia, and New Zealand post independent. They acknowledge their strategic geopolitical importance between China and Australia in the Pacific, and will look to exploit the issue to further improve Bougainville economy once independent is granted. It is also important to note that they still have internal issue to iron out especially in the matter concerning trust among clan and groups. The Bougainville civil war which follows the secessionist conflict took a toll on the erosion of unity and togetherness among Bougainvillean. Some Bougainvillean also blame mining as a root causes of conflict plaguing the islands and oppose the idea to reopen the mine, especially if it would be run by another foreigner. There is no doubt that independent Bougainville would be able to sustain themselves economically, but the issue of heterogeneity will become the main challenges for them. 


\section{References}

BBC. Bougainville Referendum: PNG Region Votes Overwhelmingly for Independence, https://www.bbc.com/news/world-asia-50739203 [December 21, 2020]

Buchanan, A. (1997). Theories of Secession. Philosophy and Public Affairs Vol. 26 No. 1.

Busquets, P. B. (2020). Morality and Legality of Secession: A Theory of National Self-Determination. Switzerland: Palgrave Macmillan.

Bohane,B. The Bougainville Referendum and Beyond, https://www.lowyinstitute.org/publications/bougainville-referendum-and-beyond [December $21,2020]$

CIA. World Factbook: Papua New Guinea, https://www.cia.gov/library/publications/the-worldfactbook/geos/pp.html [December 21, 2020]

Connell, J. (2020). Bougainville: A New Pacific Nation?. Small States \& Territories Vol. 3 No. 2.

Ganguly, R., \& Macduff, I. (2003). Ethnic Conflict and Secessionism in South and Southeast Asia: Causes, Dynamics, and Solutions. New Delhi, India: SAGE India.

Government of Australia. History of Bougainville Conflict, https://www.aph.gov.au/parliamentary_business/committees/house_of_representatives_commi ttees?url=jfadt/bougainville/bv_chap2.pdf [Accessed December 21, 2020]

Government of New Zealand. NZ Congratulates PNG and Autonomous Bougainville Government on Referendum, https://www.beehive.govt.nz/release/nz-congratulates-png-and-autonomousbougainville-government-referendum [Accessed December 21, 2020]

Islam, M. R. (1991). Secession Crisis in Papua New Guinea: The Proclaimed Republic of Bougainville in International Law. University of Hawaii Review Vol. 13 No. 2.

Laracy, H. (1991). Bougainville Secessionism. Journal de las Sociéte des Océanistes No. 92.

Matthew, A. (2000). Bougainville and Papua New Guinea: Complexities of Secession in a MultiEthnic Developing State. Political Studies Vol. 48 No. 4.

Pavkovic, A., \& Radan, P. (2011). The Ashgate Research Companion to Secession. London, UK: Routledge.

Regan, A. (1997). Causes and Course of the Bougainville Conflict. Journal of Pacific History Vol. 33 No. 3.

Regan, A. (2018). The Bougainville Referendum Arrangements: Origins, Shaping, and Implementation. Australian National University Discussion Paper 2018/4.

Walzer, Michael. (1977). Just and Unjust War: A Moral Argument with Historical Illustration, New York, Basic Books. 